\title{
Peningkatan Minat Budi Daya Melalui Pelatihan Produksi Pakan Ikan Mandiri dan Akuaponik
}

\author{
Anis Zubaidah ${ }^{1 *}$, Ganjar Adhywirawan Sutarjo ${ }^{1}$, Nur Ocvanny Amir ${ }^{2}$, Ridho Firmandhaka ${ }^{1}$ \\ ${ }^{1}$ Prodi Akuakultur, Fakultas Pertanian Peternakan, Universitas Muhammadiyah Malang \\ ${ }^{2}$ Prodi Agribisnis, Fakultas Pertanian Peternakan, Universitas Muhammadiyah Malang
}

Submisi: 04 Oktober 2019 ; Revisi: 20 April 2020; Penerimaan: 28 April 2020

\begin{abstract}
Kata Kunci:
Ikan lele

Ketahanan

pangan

Pakan

alternatif

Remaja

\section{Alternative feed \\ Catfish \\ Food}

Keywords:

security

Teenagers

Abstrak Remaja merupakan figur yang sangat berperan dalam proses pembangunan nasional dan mentalitas nasional. Aktivis pemuda di Dusun Jetis, Desa Mulyoagung dipilih sebagai mitra target dalam program kemitraan ini karena dianggap mampu menjembatani pengusul dengan masyarakat. Tujuan kegiatan ini adalah untuk meningkatkan keterampilan remaja di bidang pertanian dan perikanan melalui pelatihan pembuatan pakan ikan mandiri dan budi daya ikan menggunakan sistem akuaponik demi mencapai ketahanan pangan nasional melalui pengembangan potensi lokal. Metode yang digunakan dalam kegiatan ini adalah pelatihan secara langsung tentang teknik pembuatan pakan ikan secara mandiri dengan memanfaatkan bahan baku lokal dan pelatihan budi daya ikan menggunakan sistem akuaponik. Hasil dari kegiatan ini adalah peningkatan ketertarikan remaja terhadap akuaponik sebesar $30 \%$ dan peningkatan pemahaman remaja tentang pembuatan pakan ikan sebesar $30 \%$. Kesimpulan dari kegiatan ini adalah bahwa pelatihan dapat meningkatkan ketertarikan dan pemahaman remaja perihal akuaponik dan pembuatan pakan ikan mandiri sehingga di masa mendatang diharapkan akan semakin banyak remaja yang menekuni bidang pertanian dan perikanan.

Abstract Teenagers are figures who are very involved in the process of national development and national mentality. Youth activists in Jetis, Mulyoagung village were chosen as target partners in this engagement program because they were considered capable of bridging the proposer and the community. The purpose of this activity is to improve the skills of the teenagers in agriculture and fisheries through training the aquaponic system and produce alternative fish feed for the sake of achieving national food security through developing local potential. The method used in this activity is training on how to make alternative fish feed by utilizing local raw materials and training in aquaculture using an aquaponic system. The results showed that teenage interest in aquaponics increased by $30 \%$ and understanding the production of alternative fish feed also increased by $30 \%$. The conclusion obtained from this activity is that additional training can increase the interest and understanding of teenagers in aquaponics and the production of alternative fish feed, so hoped that more teenagers will pursue agriculture and fisheries.
\end{abstract}

\section{PENDAHULUAN}

Sektor perikanan merupakan salah satu sektor yang dapat menunjang pertumbuhan ekonomi di Indonesia. Pembangunan budi daya perikanan berpeluang besar untuk dilakukan apabila dilihat dari lingkungan strategis dan potensi sumber daya yang tersedia. Selain itu, peningkatan jumlah penduduk dunia yang menyebabkan kebutuhan ikan semakin meningkat, pergeseran pola konsumsi masyarakat ke produk perikanan, serta tuntutan penyediaan makanan bermutu

ISSN 2460-9447 (print), ISSN 2541-5883 (online)

${ }^{*}$ Corresponding author: Zubaidah

${ }^{1}$ Prodi Akuakultur, Fakultas Pertanian Peternakan, Universitas Muhammadiyah Malang, Jl. Raya Tlogomas 246, Tegalgondo, Karang Ploso, Jawa Timur, Indonesia

Email:aniszubaidah@umm.ac.id 
tinggi dan memenuhi syarat kesehatan menjadi alasan pentingnya pembangunan budi daya perikanan. Sayangnya, kemajuan teknologi di era globalisasi saat ini justru tidak berpihak pada penyediaan sumber daya manusia yang mumpuni di bidang perikanan. Hal tersebut sesuai dengan pernyataan dari Kementerian Kelautan dan Perikanan bahwa milenial tidak tertarik pada bidang perikanan (Victoria, 2019).

Pada era globalisasi yang ditandai dengan perubahan yang begitu cepat dan tidak terduga akibat kemajuan teknologi komunikasi dan informasi, generasi milenial (remaja) mudah menjadi korban dari setiap perubahan dan perkembangan (Taopan et al., 2019). Perubahan yang berpengaruh besar pada kehidupan generasi milenial adalah perubahan yang terkait dengan kegiatan ekonomi dan perkembangan teknologi. Saat ini, kurangnya minat remaja untuk terjun di bidang perikanan menjadi hal yang perlu diperhatikan karena dapat mengancam ketahanan pangan nasional (Romdiyati, 2015). Saat ini semakin banyak desa yang ditinggalkan oleh para remajanya untuk bekerja di kota-kota besar yang lebih menjanjikan daripada menjadi petani atau pembudi daya ikan. Selain itu, banyak remaja yang menjadi pengangguran karena tidak memiliki keterampilan, padahal persaingan di bidang industri sangat tinggi.

Para remaja umumnya berpikir bahwa budi daya ikan adalah pekerjaan yang melelahkan, membosankan, dan harus berpanas-panasan, hujan-hujanan, serta menunggu lama untuk mendapat hasil panen yang memuaskan dan mendapatkan uang. Selain itu, budi daya ikan dipandang sebagai pekerjaan kelas dua. Pandangan tersebut diperkuat dengan masih sempitnya kesadaran dan pemahaman masyarakat tentang pentingnya potensi lokal. Paradigma tersebut dapat berimbas pada sektor perikanan, terutama sektor ketahanan dan kedaulatan pangan di Indonesia pada masa yang akan datang karena berkurangnya minat remaja menjadi pembudi daya. Dalam bidang perikanan, remaja diharapkan mampu menciptakan sistem atau konsep-konsep baru, bahkan teknologi baru yang dapat digunakan untuk memaksimalkan produktivitas meskipun dengan lahan yang minim dan memanfaatkan potensi lokal daerah masing-masing.

Desa Mulyoagung terletak di ketinggian rata-rata \pm 600 mdpl dan berhawa sejuk karena terletak di kawasan lereng gunung. Desa Mulyoagung merupakan desa tujuan perpindahan penduduk dari kota dan luar daerah/ provinsi. Hal tersebut menyebabkan penduduk Desa Mulyoagung bersifat heterogen dan tata cara kehidupan penduduknya yang semula bersifat pedesaan berubah menjadi perkotaan. Kehadiran para pendatang juga berpengaruh terhadap mata pencaharian penduduk yang kemudian didominasi oleh pengusaha/ swasta, yaitu sebesar $49 \%$. Penduduk yang bertani (termasuk di dalamnya pembudi daya ikan) jumlahnya menurun dibandingkan tahun 2010, yaitu hanya sebesar $12 \%$ (Desa Mulyoagung, 2013). Penurunan tersebut juga perlu diperhatikan karena dapat berpengaruh terhadap ketahanan pangan nasional.

Desa Mulyoagung terdiri atas beberapa dusun. Setiap dusun memiliki kumpulan remaja yang tergabung dalam karang taruna. Di Dusun Jetis, misalnya, terdapat \pm 20 remaja yang aktif dalam karang taruna. Remaja penggerak karang taruna di Dusun Jetis inilah yang dipilih sebagai target mitra dalam program kemitraan ini karena dianggap mampu menjembatani antara pengusul dengan masyarakat. Dalam program ini, mereka diikutsertakan dalam pelatihan pembuatan pakan ikan mandiri dengan memanfaatkan potensi lokal dan pelatihan pembudidayaan ikan dengan sistem akuaponik. Akuaponik merupakan gabungan teknologi budi daya ikan dan tanaman dalam satu wadah (Fathulloh \& Budiana, 2015). Teknologi tersebut telah dimanfaatkan oleh negara-negara maju, khususnya yang memiliki keterbatasan lahan untuk mengoptimalkan produktivitas biota perairan dan terbukti dapat meningkatkan kapasitas produksi serta perbaikan kualitas air (Nugroho et al., 2012). Pelatihan ini diharapkan dapat meningkatkan keterampilan remaja, khususnya di bidang pertanian dan perikanan demi pencapaian ketahanan pangan nasional melalui pengembangan potensi lokal.

\section{METODE}

Program ini dilaksanakan selama delapan bulan (Mei sampai Desember 2019) pada Karang Taruna Desa Mulyoagung, Kecamatan Dau, Kabupaten Malang. Metode yang digunakan adalah pelatihan bertahap.

\subsection{Pelatihan budi daya ikan dan sayuran dengan metode akuaponik}

Pelatihan dilakukan dengan memberikan bantuan teknologi dan benih untuk budi daya ikan dengan sistem akuaponik, memberikan dua buah kolam serta sarana dan prasarana lengkap untuk budi daya akuaponik kepada mitra, serta melakukan pelatihan teknik budi daya ikan dengan cara yang benar dan sesuai dengan Cara Budi Daya Ikan yang Baik (CBIB) (Direktorat Jenderal Perikanan Budi Daya, 2008).

Pelatihan dimulai dengan membersihkan lahan, meratakan permukaan tanah, merakit besi sebagai rangka kolam berbentuk bundar, dan memasang terpal (Gambar 3). Langkah selanjutnya adalah menata sistem akuaponik serta melakukan persiapan penebaran ikan dan penyemaian bibit sayuran. Persiapan penebaran ikan dilakukan dengan aklimatisasi (meletakkan ikan yang ada dalam kantong plastik ke dalam kolam hingga plastik mengembun) selama \pm 30 menit. Setelah itu, ikan siap ditebarkan di kolam. Penyemaian bibit 
dilakukan pada trypot plastik (pot untuk penyemaian benih) dengan menggunakan media tanah yang telah diberi pupuk. Setelah bibit tumbuh setinggi $\pm 10 \mathrm{~cm}$, bibit tersebut dipindahkan ke pot plastik dan diletakkan di lubang akuaponik (Gambar 1).

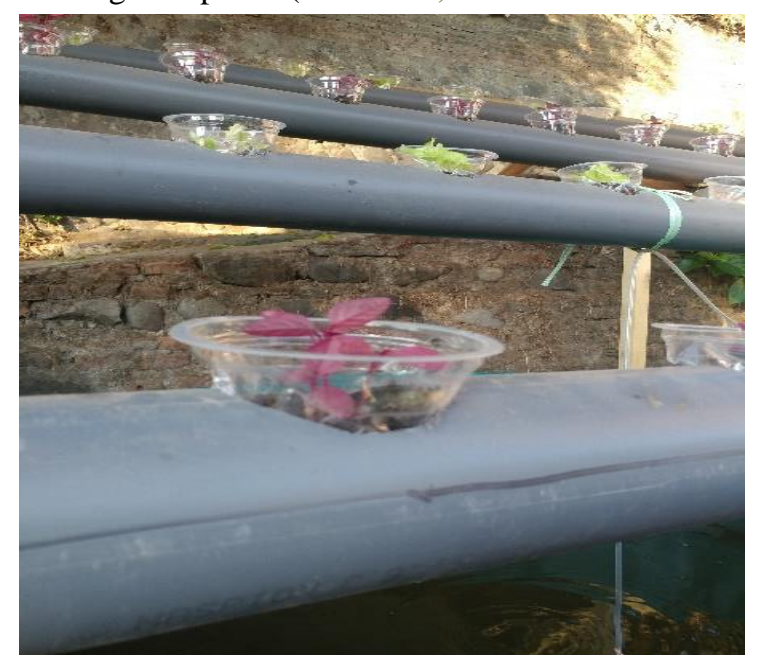

Gambar 1. Peletakkan bibit pada akuaponik

\subsection{Pelatihan pembuatan pakan ikan mandiri berbasis potensi lokal}

Penyusunan formulasi pakan dilakukan dengan program Microsoft Excel untuk menyesuaikan komposisi dan kandungan nutrisi bahan hingga diperoleh kadar protein yang diinginkan, yaitu $\pm 30 \%$. Bahan-bahan yang digunakan dalam proses pembuatan pakan antara lain tepung silase ikan, tepung daun singkong, tepung tapioka, bekatul, vitamin mix, dan molasse. Bahan-bahan tersebut kemudian diformulasikan sesuai dengan kebutuhan nutrisi ikan lele (Tabel 1). Formulasi pakan ikan dibuat oleh tim berdasarkan beberapa hasil penelitian tentang bahan penyusun pakan ikan alternatif (Zubaidah, 2011; Lazaroni \& Sutarjo, 2013).

Tabel 1. Komposisi bahan pakan ikan lele

\begin{tabular}{lc}
\hline \multicolumn{1}{c}{ Bahan Pakan } & Komposisi (\%) \\
\hline Tepung silase ikan & 40 \\
Tepung daun singkong & 20 \\
Tepung tapioka & 15 \\
Bekatul & 15 \\
Vitamin mix & 5 \\
Molasse & 5
\end{tabular}

Evaluasi kualitas pakan ikan mandiri dilakukan dengan menganalisis proksimat pakan di Laboratorium Nutrisi Jurusan Perikanan, Universitas Muhammadiyah Malang.

\subsection{Evaluasi pelaksanaan program}

Evaluasi pelaksanaan program dilakukan sebelum dan setelah kegiatan. Proses evaluasi dilakukan dengan metode wawancara dan pengisian kuesioner tentang keberhasilan program, baik secara fisik maupun respons khalayak sasaran atau mitra dan masyarakat setempat melalui partisipasi aktif dan penerapan keterbaruan teknologi. Data yang diperoleh kemudian disajikan dalam bentuk grafik dan dianalisis secara deskriptif.

\section{HASIL DAN PEMBAHASAN}

Kegiatan yang telah dilaksanakan meliputi pelatihan dan pendampingan budi daya ikan menggunakan sistem akuaponik serta pelatihan pembuatan pakan ikan mandiri.

\subsection{Pelatihan dan pendampingan budi daya ikan dengan sistem akuaponik}

Pelatihan dan pendampingan budi daya ikan dengan sistem akuaponik dilaksanakan di lokasi mitra. Pelatihan dimulai dengan pemberian sumbangan instalasi akuaponik, terdiri atas kolam terpal bundar berdiameter 1,5 $\mathrm{m}$ sebanyak dua buah yang dilengkapi dengan setting aerasi, inlet, dan outlet serta sarana dan prasarana untuk hidroponik. Kegiatan dilanjutkan dengan setting kolam dan akuaponik serta pengelolaan air untuk persiapan budi daya tanaman dan sayuran. Tujuan pelatihan ini adalah memberikan pemahaman kepada mitra terkait persiapan budi daya dan sistem budi daya untuk mendapatkan hasil yang optimal. Kegiatan ini diharapkan dapat memotivasi remaja karang taruna di Dusun Jetis untuk mengembangkan budi daya ikan demi ketahanan pangan di masa mendatang. Berdasarkan hasil evaluasi diperoleh data peningkatan minat budi daya pada remaja Karang Taruna Dusun Jetis, Desa Mulyoagung setelah pelaksanaan kegiatan pelatihan (Gambar 2).

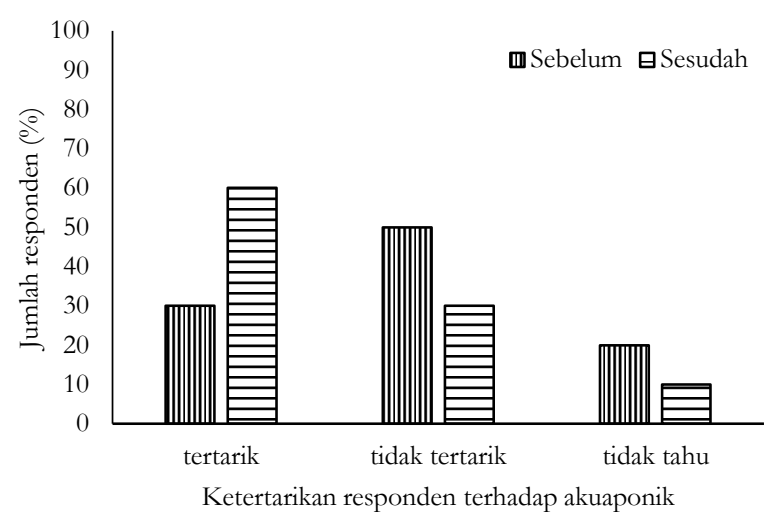

Gambar 2. Ketertarikan responden terhadap akuaponik sebelum dan sesudah pelatihan

Ketertarikan remaja karang taruna di Dusun Jetis pada sistem akuaponik dipengaruhi oleh berbagai faktor, antara lain faktor biaya dan penghasilan serta keterampilan yang berkaitan dengan akuaponik Sebelum ada kegiatan pelatihan, mereka mengaku hanya mengetahui kegiatan akuaponik dari media massa tanpa mengetahui kerja sistem tersebut serta teknik membuat rangkaiannya. 
Pelatihan ini dapat memberikan pemahaman kepada remaja karang taruna di Dusun Jetis terkait budi daya ikan dengan sistem akuaponik. Prinsip kerja akuaponik adalah mengalirkan air kolam ke dalam talang-talang air yang sudah dilengkapi dengan media tanam serta bibit tanaman. Media tanam dan akar tanaman yang tumbuh berfungsi dalam proses pengolahan air kolam yang kemudian dialirkan kembali ke dalam kolam ikan (Maharani \& Sari, 2016). Proses pengolahan air kolam dilakukan dengan cara penyerapan senyawa nitrat oleh akar-akar tanaman sebagai nutrisi untuk pertumbuhan tanaman (Damanik et al., 2018). Kegiatan budi daya ikan dengan sistem akuaponik juga dapat diterapkan pada lahan sempit serta tidak membutuhkan kerja ekstra dalam pelaksanaannya. Hal inilah yang kemudian meningkatkan jumlah mitra target yang tertarik terhadap akuaponik, yakni yang sebelumnya hanya berjumlah $30 \%$ kemudian menjadi $60 \%$.

\subsection{Pelatihan pembuatan pakan ikan mandiri}

Dalam usaha budi daya ikan, pakan merupakan komponen utama yang membutuhkan biaya produksi paling tinggi (70\%) (Purwadi, 2016). Oleh karena itu, keterampilan dalam membuat pakan mandiri merupakan hal wajib yang perlu dimiliki oleh setiap pembudi daya. Hal tersebut yang mendasari pelaksanaan pelatihan pembuatan pakan ikan mandiri. Pelatihan dilaksanakan pada 14-21 Juli 2019. Tujuan pelatihan adalah untuk membekali remaja karang taruna di Dusun Jetis dengan keterampilan membuat pakan ikan sehingga dapat menekan biaya produksi. Pelatihan ini juga menekankan pemanfaatan kearifan lokal guna meningkatkan nilai tambah dan mengurangi polusi (limbah). Kegiatan ini diikuti dengan antusias oleh peserta. Hal itu terlihat dari keaktifan peserta dalam sesi diskusi dan proses pembuatan akuaponik (Gambar 3).

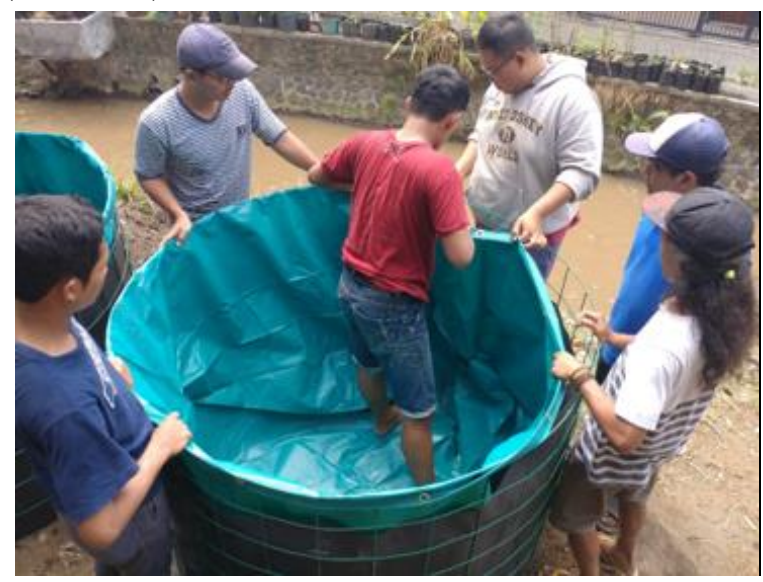

Gambar 3. Kegiatan pemasangan kolam untuk akuaponik

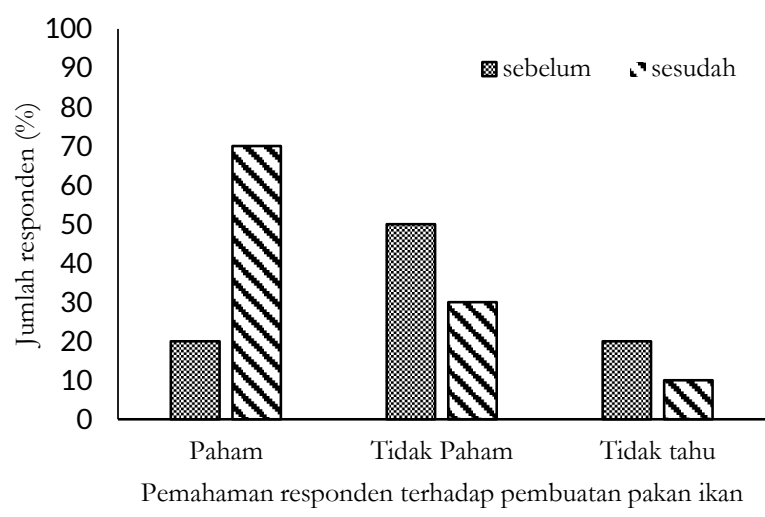

Gambar 4. Peningkatan pemahaman remaja terkait pembuatan pakan ikan dengan bahan baku berbasis potensi lokal

Berdasarkan Gambar 4 di atas diketahui bahwa terdapat peningkatan pemahaman remaja yang signifikan terkait produksi pakan ikan secara mandiri dengan memanfaatkan bahan-bahan alternatif. Pakan ikan merupakan parameter terpenting dalam usaha budi daya perikanan. Ketersediaan jumlah pakan sangat berpengaruh pada pertumbuhan dan kelangsungan hidup ikan yang dibudidayakan. Pada proses budi daya ikan, khususnya dalam kegiatan pembesaran, faktor terpenting adalah jumlah ketersediaan pakan yang cukup.

Setelah pelatihan terdapat peningkatan pemahaman remaja terkait produksi pakan ikan secara mandiri dengan memanfaatkan bahan-bahan alternatif. Pakan ikan merupakan parameter terpenting dalam usaha budi daya ikan. Ketersediaan jumlah pakan sangat berpengaruh pada pertumbuhan dan kelangsungan hidup ikan yang dibudidayakan. Pada proses budi daya ikan, khususnya pada fase pembesaran, faktor yang terpenting adalah ketersediaan pakan yang cukup.

Salah satu bahan baku alternatif yang dapat digunakan untuk membuat pakan ikan adalah tepung daun singkong. Tepung daun singkong memiliki kandungan protein sebesar 30,24\%, lemak 5,60\%, dan serat kasar 15,80\% (Syahrizal et al., 2013). Oleh karena itu, bahan baku daun singkong dapat dimanfaatkan dalam formulasi pakan ikan untuk mencukupi kebutuhan protein nabati dan mengganti ketersedian bahan baku kedelai yang terbatas. Selain itu, pemanfaatan tepung daun singkong juga bertujuan untuk menekan biaya pembuatan pakan sehingga harganya lebih terjangkau. Hasil penelitian yang telah dilakukan oleh Suwarsito et al., (2017) menunjukkan bahwa pemberian tepung daun singkong dapat berpengaruh nyata terhadap pertambahan berat dan panjang ikan nila. Pakan ikan hasil kegiatan pelatihan dapat dilihat pada Gambar 5. 


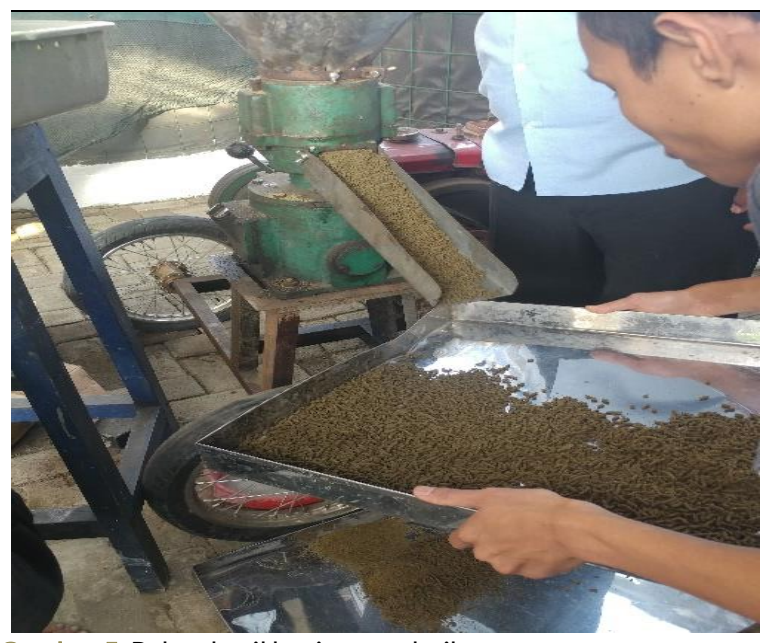

Gambar 5. Pakan hasil kegiatan pelatihan

Ikan dan sayuran yang dihasilkan dari kegiatan ini memiliki keunggulan, yakni bersifat organik, aman, sehat, dan halal karena dipelihara dengan cara higienis dan tanpa menggunakan bahan-bahan kimiawi (sintetis). Pakan ikan yang dihasilkan juga diharapkan akan dapat bersaing dengan kualitas pakan ikan pabrikan. Harga pakan mandiri juga lebih terjangkau, yaitu Rp. 8.500/ kg daripada harga pakan produksi pabrik, yaitu Rp. 12.500/ kg.

\section{KESIMPULAN}

Kegiatan pelatihan pembuatan pakan ikan mandiri dan budi daya ikan dengan sistem akuaponik yang diikuti oleh pemuda Karang Taruna Dusun Jetis, Desa Mulyoagung, Kabupaten Malang dapat dilaksanakan dengan baik dan lancar. Manfaat kegiatan yang telah dilaksanakan adalah memberikan pengetahuan baru dan meningkatkan minat peserta perihal budi daya ikan dan sayuran dengan sistem akuaponik serta pembuatan pakan ikan secara mandiri. Kegiatan ini juga dapat meningkatkan pemanfaatan sumber daya lokal dan pemenuhan pangan lokal secara mandiri.

\section{UCAPAN TERIMA KASIH}

Kegiatan ini terlaksana berkat pendanaan dari Kementrian RISTEKDIKTI dengan skema PkM (Pengabdian kepada Masyarakat) 2019.

\section{DAFTAR PUSTAKA}

Damanik, B. H., Hamdani, H., Riyantini, I., \& Herawati, H. (2018). Uji efektivitas bio filter dengan tanaman air untuk memperbaiki kualitas air pada sistem akuaponik ikan lele sangkuriang (Clarias gariepinus). Jurnal Perikanan dan Kelautan, 9(1): $134 \quad-\quad$ 142. Diakses dari http://jurnal.unpad.ac.id/jpk/article/view/18233

Desa Mulyoagung. (2013). Gambaran Umum Desa Mulyoagung. Diakses dari https://desamulyoagung.blogspot.com/
Direktorat Jenderal Perikanan Budi Daya. (2008). Cara Budi Daya Ikan yang Baik (CBIB). Kementerian Kelautan dan Perikanan, Jakarta.

Fathulloh, A. S. \& Budiana, N. S. (2015). Akuaponik Panen Sayur Bonus Ikan. Jakarta: Penebar Swadaya.

Lazaroni, J. L. \& Sutarjo, G. A. (2013). Pengaruh Pemanfaatan Silase Ikan sebagai Bahan Penyusun Diet terhadap Retensi Protein, Retensi Lemak dan Kualitas Daging Ikan Sidat (Anguilla bicolor) (Laporan Penelitian). Jurusan Perikanan UMM Malang.

Maharani, N. A. \& Sari, P. N. (2016). Penerapan Aquaponic sebagai Teknologi Tepat Guna Pengolahan Limbah Cair Kolam Ikan di Dusun Kergan, Tirtomulyo, Kretek, Bantul, Yogyakarta. Indonesian Journal of Community Engagement, 1(2): 172-182. Diakses dari https://jurnal.ugm.ac.id/jpkm/article/view/10603

Nugroho, R. A, Pambudi, L. T, Chilmawati, D., \& Haditomo, A. H. C. (2012). Aplikasi Teknologi Aquaponic pada Budi Daya Ikan Air Tawar untuk Optimalisasi Kapasitas Produksi. Jurnal Saintek Perikanan, 8(1): 46-51. Diakses dari https://doi.org/10.14710/ijfst.8.1.46-51

Purwadi. (2016). Peternak Mengeluh, 70\% Biaya untuk Pakan. Diakses dari https://www.radarcirebon.com/peternakmengeluh-70-persen-biaya-untuk-pakan. html/

Purwaningsih. (2008). Ketahanan Pangan: Situasi, Permasalahan, Kebijakan, dan Pemberdayaan Masyarakat. Jurnal Ekonomi Pembangunan, 9(1): 1-27. DOI:10.23917/jep.v9i1.1028

Romdiyati. (2015). Minat Bertani Generasi Muda Menurun, Indonesia Terancam Krisis Petani. Diakses dari https://lipi.go.id/

Suwarsito, Apreli, N. N., \& Mulia, D. S. (2017). Pengaruh pemberian kombinasi tepung daun singkong (Manihot utilisima) dan tepung ikan rucah terhadap pertumbuhan dan kelangsungan hidup ikan nila (Oreochromis niloticus). Sainteks, $14(2), \quad 105 \quad-\quad 112$. DOI;10.30595/sainteks.v14i2.4258

Syahrizal, Ghofur, M., \& Fakhrurrozi. (2013). Pemanfaatan Daun Singkong (Manihot utilissima) Tua sebagai Pakan Ikan Gurami (Osphronemus gouramy. Lac). Jurnal Ilmiah Universitas Batanghari Jambi, 13(4), 107-112. https://media.neliti.com/media/publications/225 613-pemanfaatan-daun-singkong-manihotutilis-dfc1d253.pdf

Taopan Y. F., Oedjoe, M. R., \& Sogen, A. N. (2019). Dampak Perkembangan Teknologi Informasi dan Komunikasi terhadap Perilaku Moral Remaja di SMA Negeri 3 Kota Kupang. Jurnal Kependidikan: Jurnal Hasil Penelitian dan Kajian Kepustakaan di Bidang Pendidikan, Pengajaran, dan Pembelajaran, 5(1), 61-74. Diakses dari http://ojs.ikipmataram.ac.id/index.php/jurnalkep endidikan/article/view/1395 
Victoria, A. O. (2019). Kementerian KKP Keluhkan Generasi Milenial Tak Tertarik Bidang Perikanan. Diakses dari https://katadata.co.id/berita/2019/10/12/kemente rian-kkp-keluhkan-milenial-tak-tertarik-bidangperikanan/
Zubaidah, A. (2011). Pengujian Berbagai Bahan Perekat terhadap Kualitas Kimia Pakan Ikan (Skripsi). Universitas Muhammadiyah Malang, Malang. 